\title{
GOVERNMENT AND SLUM HOUSING: SOME GENERAL CONSIDERATIONS
}

\author{
LaWrence M. Friedman*
}

Housing was a latecomer to the federal trough. The federal government historically made war, killed Indians, gave away land, tried cases, raised taxes, regulated business, and appropriated money. It hardly ever built houses, except for itself, its soldiers, and its prisoners. But in the last generation or so, the federal government has begun to make up for lost time. It has begun building and financing houses. The Wagner Housing Act, enacted in $1937,{ }^{1}$ was only a first step. The federal housing effort now has a cabinet department of its own-a status higher than that of food and drugs, the Army, and social security, all of which have to be content with representation at the sub-cabinet level. The new status is evidence of a new emphasis-or at least evidence of a nagging feeling in society that something is wrong and that something must be done. Specifically, what is wrong is the slums.

It is still a question, however, whether the main federal effort in housing will go toward slum housing or toward something else. In the r93os stress was placed on housing the lower working class. In the I940s defense workers and veterans were the prime beneficiaries of federal action. In the 1950s emphasis was placed on middleincome housing in the suburbs, and upper-income housing in the renewed urban core. Only in the Ig6os does it seem even possible that the desperate urban poor will move to the center of the stage. And even that is an open question.

Government emphasis (and money) is never a matter of whim. It is a matter of cash and of votes; of letters from home addressed to Congress; of riots and lawsuits and pressures. Concrete social forces have determined why government has done what it has done in the field of housing. Concrete social forces have similarly determined why it has not done the things that have not yet been done. This short overview will discuss the federal effort to eliminate the slums and provide decent homes for the poorest of the poor, in terms of the social forces that have made the job so far so hard. Clearly the slums have not been eliminated. Clearly many of the poor remain locked in their ghettos, in dark, dank, overcrowded rooms. Clearly, the situation is unhappy. Can we shed any light on the causes and cures?

\section{I}

Slum Housing: The Problem

It is natural for people to think of problems in absolute terms. Most people

* A.B. 1948, J.D. 195I, LL.M. 1953, University of Chicago. Professor of Law, University of Wisconsin. Author, Contract Law in America (I965); Government and Slum Housing: A Century of Frustrarion (in press, 1967 ). The author's current research on housing and social legislation is supported by the Institute for Research on Poverty at the University of Wisconsin.

1 United States Housing Act of 1937 , ch. 896,50 Stat. 888. 
believe that air pollution, the population explosion, the gold flow, and increasing crime rates are threats to humanity in an objectively measurable sense. Yet it is important to note that a problem is also-and primarily-a state of mind. A problem is a situation that worries some segment of the population. If there is no worry, there is no problem. The air remains polluted, but there is no pressure for political and social action. A "problem" exists, then, only to the extent it is so perceived. Otherwise, it is like the noise of a tree falling in an empty forest.

There is no question, at least not now, that slum housing is a problem. Three groups of people see it that way. One group is composed of some of the people who live in the slums. Another is composed of some outsiders. The third is made up of some elected and appointed government officials. But each group sees the problem in a very different light.

The person who lives in the slums, if he thinks of his housing condition as a problem, feels his situation as a personal trouble. It is a deficiency in his own standard of living, a source of discomfort, stigma, and pain. The outsider cannot see slum housing in this way: his own house is in order. His perception of the slum housing problem, then, cannot be the same as that of the poor themselves. The outsider may have, instead of a perception of a problem, a perception of an interest. Some people have a direct, material stake in government housing programs. Among these are manufacturers of building supplies and labor unions whose members are bricklayers and masons. Similarly, cement companies have a direct interest in the federal highway program. This kind of interest has played an important and pervasive role in the history of Government's housing effort. Building-trade unions, for example, lobbied vigorously for passage of the New Deal public housing law. ${ }^{2}$ Landlords with vacant apartments in marginal neighborhoods welcome the new leasing program ${ }^{3}$ with open arms, since it promises to put federal rent money in their pockets.

Most people, however, lack strong material interests in any particular item of legislation. Slum housing affects them only obliquely. Many people do feel that slum housing is a threat, not to them individually and directly, but indirectly, because it is a threat to the collectivity of which they are a part. One might call this the social interest. In a way it differs from direct interests only in degree. The citizen may oppose air pollution because a factory next door is pouring malodorous smoke in his window, or because the air in a city he likes to visit is slightly brown and acrid in the gills. Both problems affect him, but in different ways. Vast numbers of people feel a social interest in a wide range of problems.

The first laws that had anything whatsoever to do with slum housing were fire laws. ${ }^{4}$ Fires can begin in the slums and spread to the better parts of town. They endangered some people directly, but many more indirectly. It has always been easy to

\footnotetext{
T. McDonneli, The Wagner Housing ACt II6-23 (1957).

${ }_{42}$ U.S.C. $\$ 142 \mathrm{xb}$ (Supp. II, 1965-66).

${ }^{1}$ E.g., Act of May 3, I895, ch. 355, [1895] Wis. Laws 719.
} 
denounce the slums, not for any welfare motive or motive of heart, but because the slum threatens the safety of his city. Similarly, the slums have been called a social danger because they are alleged to breed crime, socialism, boss-rule, or disease. Jacob Riis told the world that the tenements were "hot-beds of the epidemics that carry death to rich and poor alike; the nurseries of pauperism and crime," which bred "a scum of ... human wrecks ... [and] maintain a standing army of ten thousand tramps." The Boston Anti-Tenement House League helped induce Massachusetts to enact a law "to Prevent the Manufacture and Sale of Clothing Made in Unhealthy Places." The idea was that in tenement sweatshops, dread germs were transmitted to the clothes. These germs spread sickness to the people who bought and wore the clothes. Any reader can think of pungent contemporary examples-appeals to reform the slums in order to roll back Communism or achieve some other social result.

Finally, there is pure disinterest-the reform motivation. Some people have worked to improve the life of the poor for no outward reasons of personal or social gain. Conscience and conviction have been powerful engines of social change. The history of housing legislation has been full of individual heroes-men like Jacob Riis, or Lawrence Veiller, who was the soul and spirit behind the New York Tenement House Law of 1907.7 Reformers cannot, as a general rule, induce people to betray what they consider their direct individual interests. But they can persuade people where their indirect, social interests lie. Hence reformers have been enormously important, as catalysts and propagandists.

What is the interest of government? There are, to be sure, bureaucratic interests. Department heads will fight tooth and nail to get a program into their bailiwick rather than someone else's. They will lobby for programs that strengthen their position or aggrandize their empire. But in general, the governmental interest is quite different from the nongovernmental interest. Abstractly stated, it is the interest in satisfying the most outside demands at the least possible cost to itself.

The governmental interest is worth dwelling on. In some ways, it is the critical interest. The subject matter of this article is a body of law: enacted programs of government. But government is not usually an initiator; it reacts. It responds to demands made upon it. These demands are evoked by other people with interests, direct or indirect, in situations which appear to the demandants as problems. Government responds; but it filters demands through the special needs of government as an institution or a system. The basic need is for equilibrium, for balance, for stability. It is a need to respond while incurring as little cost as possible, and running as few risks as possible. Now cost is not meant in a narrow literal sense. Losing an election is a cost to a Congressman or President, indeed, the highest cost of all. Some responses to demands call for costs in the obvious monetary sense. If a program

${ }^{5}$ J. Riss, How the Other Hate Lives 3 (Igo6).

- Act of May 28, x891, ch. 357, [1891] Mass. Acts \& Resolves 922.

"See generally R. Lubove, The Progressives and the Siums (I96z). 
promises to be expensive, taxes may have to be raised. Or alternative programs may have to be foregone. But these may cause grumbling, disturbances, angry letters, threats to withhold votes and contributions, or even riots in extreme cases. The ideal program would be one that pleased everybody. Such programs, needless to say, are few and far between. All others involve a measure of cost.

The remarks above are elementary and perhaps hardly worth the mention. But the course of housing history makes no rational sense from any other point of view. The history of housing legislation, all in all, makes no ethical sense, no economic sense, no social sense. But it makes sense in terms of the system needs of political bodies. Yet this dimension is frequently ignored. The rise of a federal housing program is often taken to be a sign that good is finally prevailing over evil. Social scientists have discarded as useless the notion of progress-a one-line movement of society from the bad to the good. But the concept of progress hangs on in the folk mind with an iron grip. Ideas of good and bad are valuable, even necessary. They tell us what to work for. But they are very bad at explaining the past. The past is best accounted for by rigorous search for direct and indirect interests, among the relevant actors, and by careful consideration of the governmental interest. Government, after all, is a crucial player in the game. Government, the body that makes and enforces law, is a vast institution; and it is made up of ordinary men. To assume that these men are inclined to maximize responses at minimum cost, is to assume only that they are terribly human. This primitive assumption brings light into fields of great darkness.

\section{II}

\section{On Majority RuLe}

Political life, in this country, follows roughly the principle of majority rule. This principle, baldly stated, is very abstract. But one can draw several corollaries from it. First, it is clear that government will ordinarily serve majority interests, not minority interests, when the two are sharply defined, and in conflict. Often enough, the two are sharply defined, and do conflict. And government sides with the loudest and most numerous voice.

In the United States, there is a huge middle class. It outnumbers by far both the rich and the poor. Hence there is a deeply ingrained, inverterate slippage of poverty programs into middle class programs. The American public housing movement itself provides one long verification of this statement. America never had any public housing to speak of until the period just after the First World War, when a few sporadic programs were launched in the states. ${ }^{8}$ Massachusetts and North Dakota (an unlikely pair) were among the pioneering states. Both programs, however, were

\footnotetext{
${ }^{8}$ During the First World War, the federal government began a program to house workers in ship. yards and defense industries. After the war, the program was quickly dismantled. Act of March I, IgI8, ch. I9, 40 Stat. 438; Act of May 16, 1918, ch. 74, 40 Stat. 550; Act of July 19, 1919, ch. 24, 4I Stat. 224. See generally R. Fisher, Twenty Yesrs of Public Housing 74-79 (1959).
} 
profoundly different from public housing as it developed in the r95os and $x 960$. Neither was really interested in the bottom level poor. These programs were rather geared toward the lower middle class. Massachusetts's plan was explicitly designed for "mechanics, laborers, wage-earners." The houses were to be small suburban cottages. The North Dakota Experiment (rgrg-I923) called for the construction of homes, financed by state funds, to be sold to residents of the state. ${ }^{10}$ Its main interest was in the simple farmer-though not the tenant farmer or the migrant farm worker. Neither plan succeeded, but not because they aimed at the wrong level of society, politically speaking. ${ }^{11}$

New Deal public housing was of course a more radical program. But it turned out to be politically feasible only during a period in which millions of the former middle class had lost their jobs but not their political voices. This was the unique situation in the days of the great depression. Vast numbers of Americans had become much poorer than they were. Yet in culture and habit, they were still members of the middle class. ${ }^{12}$ These fallen members of the middle class were to be the prime beneficiaries of public housing. They were the depression equivalent of the honest farmers and sturdy mechanics of the North Dakota and Massachusetts experiments. Hence, although public housing tenants had to be poor, they could not be too poor. They had to be able to pay the rent. The rent was heavily subsidized-but it was not by any means free. Those who could not pay it, and those who were deficient in good character, were not to be let in. ${ }^{13}$

And even at that, the heyday of public housing lasted only so long as the depression lasted. Its momentum was swept away during the Second World War. It was only natural to expend wartime and immediate post-war energy on defense workers and veterans. ${ }^{14}$ Afterwards, the major effort went into assuring middleclass migration into the suburbs. Public housing became a feeble program starved for funds. New public construction was and is lucky if it equals two per cent of private housing starts. ${ }^{15}$ Congress during the I950s came close to killing public housing altogether. The effect of public housing is cumulative, of course. More than 2,000,000 people live in public housing. They are oddly distributed, however. Almost a quarter of them are tenants of the New York City Housing Authority.

\footnotetext{
${ }^{0}$ Act of May 25, 19I7, ch. 310, [I9I7] Mass. Gen. Acts 317.

${ }^{10}$ Act of Feb. 25, I919, ch. 150, [1919] N.D. Laws 210.

${ }^{11}$ See generally D. Schaffter, State Housing Agencies 9-33, 552-67 (1942); Robinson, Publie Housing in Massachusetts, I8 B.U.L. Rev. 83 (1938).

${ }^{13}$ See generally Friedman, Public Housing and the Poor: An Overview, in The Law of the Poor 318 (J. tenBrock ed. I966).

${ }^{13}$ It is still possible to be too poor for public housing. But the rock-bottom poor are generally on welfare, and their rent payments are taken care of by welfare agencies. In I949, the federal statute was specifically amended to provide that no one was to be excluded from public housing solely because he was on welfare. Housing Act of 1949 , ch. $338, \S 301,63$ Stat. 423 . This proviso is no longer part of the federal statute but in practice welfare families are freely admitted to public housing.

${ }^{14}$ E.g., Veterans' Emergency Housing Act of 1946, ch. 268, 60 Stat. 207.

I6 See I8 HHFA ANN. REP. 386 (1964).
} 
And however one counts the poor, public housing has not been an impressive effort at housing the indigent. Public housing may not be worth doing at all. But this halfway effort is hard to justify on any theory. It is not hard to explain, however. The political zest of politicians for programs is a function of the payoff to them in honor or votes. Even the housing reformers found public housing disgusting by the late I950s; ${ }^{16}$ and the right wing, especially the real estate right, was paranoid on the subject. The only flicker of enthusiasm for the program at this low point in public housing's career was generated by programs to house the elderly. Some cities which had no interest in the usual sort of public housing mounted substantial plans for housing the elderly. A high percentage of current housing effort is going into this program. ${ }^{17}$ The program is eminently worthwhile. But so are others which are death at the box office-such as anything which even smacks of racial integration in the suburbs and in the solid middle class areas. Or any infusions of the welfare poor middle class neighborhoods.

In fact, the enthusiasm for housing the elderly is best explained on political grounds. The elderly are the last remaining pool of predominantly white, culturally middle class poor. They tend to be docile. They tend to be grateful. They create .no problems of management and no problems of discipline. Except when afflicted with the forgetfulness of age, they pay their rent on time. They do not overload the schools, since they have no children. And they can conveniently be housed in big towers in the central cities.

Race was mentioned, somewhat offhandedly, in the last paragraph. It deserves a more pointed treatment. The decline in the fortunes of public housing has gone hand in hand with the rise in the percentage of Negroes in public housing. Public housing in the big cities is central city housing; and the central cities are now predominantly Negro ghettoes. The process has been going on for a long time, but since the end of the Second World War it has vastly accelerated. Public housing in Washington, D.C., is virtually all Negro. Chicago and St. Louis have some whites .in public housing, but not many. In some other cities the percentage of Negroes rises to seventy, eighty, and ninety per cent or more. At the end of 1965 , every single tenant in Philadelphia's Raymond Rosen Apartments was Negro. This project had r,r22 dwelling units. ${ }^{18}$ The reader does not have to be told what happens to public support of public housing if public housing means Negro ghettoes. Instead of the angry marginal whites of the New Deal period, public housing in the big cities is more and more the home of the most despised and dispossessed group in America: the urban, problem-family Negro. The more this happens, the more others abandon public housing-physically, by moving out, and politically, by despising it. The worst

\footnotetext{
${ }^{16}$ E.g., Bauer, The Dreary Deadlock of Public Housing, Architectural Forum, May 1957, at 140.

${ }^{17}$ See Friedman, supra note 12, at 329.

${ }^{18}$ U.S. Dep'r of Housing and Unban Development, Low-Rent Project Directory 30 (Dec. 3 , 1965).
} 
thing about big-city public housing is not that it is shoddy and dreary. ${ }^{19}$ The worst thing is that it is despicable to live there, and that degraded, hopeless people, the victims of wreakness, fate, and prejudice, make their homes there. And the more this is true, the more the white community reacts with hostility. The very mention of public housing in the suburbs or in middle class areas is political death. Mayor Lindsay of New York seems to have the courage to speak the truth; and to demand that public housing be scattered throughout the city. But he may not have the power to carry this program out. Government must follow its line of least resistance, at least as a general rule. It must follow the will of the majority. And the will of the majority is that public housing stay put in its ghetto.

The story of public housing, then, in sum, indicates the desperate straits of a program that cannot, will not, or does not accommodate middle class interests. Another good example of the same process is the fate of Aid for Dependent Children. This too began as a kind of middle class program-for unfortunate but respectable widows. When, through demographic and economic change, it became a program primarily (or at least notoriously) for Negro women with big broods of illegitimate children, the program became unpopular to the point of crisis. It is still subject to constant congressional and local sniping. ${ }^{20}$

Government, moreover, is constantly seeking new ways to help those who are politically grateful and who count. The much touted rent supplement is a case in point. $^{21}$ As originally proposed, this was a program to benefit the lower middle class-the "rich poor" as they were called. Congress refused and restricted the program to the public housing poor. One cannot identify either side as the champions of the social underdog. That Congress is not is suggested by the fact that the right wing was as eager to restrict the scope of the rent supplement to the public housing poor as anyone. Not that the right was deaf to the entreaties of the middle class. But the spectre which haunts the right is government "competition" with private industry. Congress has been exceedingly careful-paranoid may be the better word-on this subject. One example is the provision of the federal public housing law which requires a twenty per cent gap between the "upper rental limits for admission to ... low-rent housing and the lowest rents at which private enterprise unaided by public subsidy is providing . . . a substantial supply of decent, safe, and sanitary housing."22 The rent supplement, as originally proposed, raised the fear that government might invade a private market. This the right could not abide.

For some, keeping government out of competition is a matter of economic and social principle. It is a principle which has been used to justify letting

\footnotetext{
${ }^{10}$ As if Americans had such elevated aesthetic taste! As if Levittown or the average luxury apartment were any prettier.

${ }^{20}$ See generally on the history of this program, W. BeLl, Aid to Dependent ChrLdren (1965); G. Steiner, Social. Insecunuty, The Polmics of WeIfare Ir3 (I966).

${ }^{21}$ See generally Krier, The Rent Stpplement Program of 1965: Out of the Ghetto, Into the . . . , I9 STAN. L. REv. 555 (1967).

2342 U.S.C. $\$ 1415(7)$ (b) (ii) $(1964)$.
} 
people die of malnutrition rather than have the state intervene, as if the poor were Hindu mystics starving to death for a higher cause. Fortunately, for most people, laissez faire is not a sacred principle at all. It is merely an aspect of selfishness. A selfish man is not as dangerous as an ideolog; he can always be bribed. The same real estate interests who fought public housing tooth and nail have, in some cities, engerly welcomed a I965 program under which housing authorities lease private apartments and homes. ${ }^{23}$ The program sops up nagging vacancies and gives long-term leases to landlords, with a government guarantee of the rent. It stays away from low-vacancy cities. Hence it has been, so far, highly acceptable to landlords and brokers.

The administration originally proposed a rent supplement for the "rich poor." Yet it fought hard for the congressional plan, which benefits only the public housing poor. The fight has been hard. The rent supplement has been killed at least twice. Both times the White House brought it back to life by mouth-to-mouth breathing. It seemed finally, irrevocably dead, when the summer riots of 1967 brought it back to life (along with the now famous rat control bill). Yet the altruism of the administration is rendered doubtful by their original conception; and by their willingness to fight for a rent supplement-of any kind. One suspects that the administration felt it had to have a housing program, politically speaking-almost any one would do-and a rent supplement was part of this program. And the rent supplement (in its 1965 version) was likely to make jobs, house old people, and please religious and charitable organizations.

It is a hopeful sign that everybody, even arch-conservatives, seems to think a housing program is either desirable or inevitable. Hence, "alternatives" to present programs have proliferated, with constant new ideas trotted out by this side or that. There is the Percy plan, for example, which stresses Americanism and owning-yourown-home. ${ }^{24}$ It has a quaintly archaic ring. What this plan has in mind seems to be a neat little village of bungalows, inhabited by the honest (but low-paid) working class. Its relevance to the big-city slums is minimal.

\section{III}

\section{On the Political Economy of Welfare}

The second corollary of our general proposition is that government will seek the line of financial least resistance. Costly programs mean taxes and taxes are unpopular. Or they mean foregoing genuinely popular programs. Hence direct government expenditures on housing for the poor are not as attractive as expenditures which stimulate or force somebady else to spend their money. Consequently, the history of government and housing is a long tale of attempts at stimulation and force.

${ }^{28} 42$ U.S.C. $\$ 142 \mathrm{Ib}$ (Supp. II, x965-66). A study of the the program by L. Friedman and J. Kricr will be published in a forthcoming issue of the Pennsyluania Law Review.

"st S. 1952, 90th Cong., Ist Sess. (1967). There is also a Kennedy plan: S. 2088, 90th Cong., xst Sess. (I967); S. 2100, 90th Cong., Ist Sess. (1967). 
Force is the older technique, and therefore deserves earlier mention. The first important slum control laws were the tenement house laws. Modern housing codes differ from these in a number of technical respects, but in essence, they are their lineal descendants. The first notable tenement house law was passed in New York in 1867 , shortly after a venomous cholera epidemic. ${ }^{25}$ Much more influential was the law of rgor, which was imitated in Connecticut, New Jersey, and Wisconsin. ${ }^{26}$ Modern housing codes, essentially, are products of the urban redevelopment and renewal laws. To qualify for federal gold, communities must have a "workable program." Among the prerequisites of such a program is a housing code. ${ }^{27}$ This is reason enough to explain the great rush to enact these codes. They have multiplied ten-fold or more in the last fifteen years.

Housing codes vary a great deal. But the general idea is everywhere the same. The law sets up minimum standards of decency and maintenance. Overcrowding is prohibited. Sanitary conditions are insisted upon. Houses must be kept in good repair. It is obvious to the naked eye that vast tracts in New York, Chicago, and other major cities could not possibly stand in conformity with any but the most minimal type of code. Everyone knows that the Negro ghettoes are overcrowded and that conditions in many of the tenements are appalling. Enforcement of the codes, then, is something less than perfect. The same was true of their ancestors, the tenement house laws.

Law enforcement is never a simple matter; and the likelihood of enforcement is different in different cities. A good deal depends upon the resources put into enforcement. Obviously, if the call for enforcement comes only from the minority poor, no one will listen. But apart from this an essential vice gnaws at the heart of these laws. It is that the job is basically too big for punitive sanctions to work. The punitive aspects of housing laws consist not so much in the fact that criminal penalties are appended to them (though they are), as in the fact that the social burdens under these laws are distributed in such a lop-sided way. Everyone admits it would take billions of dollars to clear the slums or upgrade them and give every American a decent home. Yet if the housing codes were perfectly enforced, every American would have a minimally decent home. This means that the codes in essence demand that landlords expend billions of dollars improving their property. But where are those billions to come from? Not from government, which offers only to pay the policeman and the inspector, but from the landlords themselves.

\footnotetext{
${ }^{25}$ Act of May 14, 1867, ch. 908, [1867] N.X. Laws 2265. See generally C. Rosenberg, The ChoLers YeARS I75-234 (1962).

${ }^{26}$ Act of June 29, 1905, ch. 178, [1905] Conn. Laws 376; Act of March 25, 1904, ch. 6I, [1904] N.J. Laws 96; Act of April I2, I90I, ch. 334, [I901] N.Y. Laws 889; Act of June 21, 1907, ch. 269, [1907] Wis. Laws 9ro. See generally R. LuBove, supra note 7, on the background of the New York law; Friedman \& Spector, Tenement House Legislation in Wisconsin: Reform and Reaction, 9 AM. J. LEGAI. HIST. 4I (1965), on the background of the Wisconsin law.

${ }^{27}{ }_{42}$ U.S.C. \$ I45I (1964, Supp. II, 1965-66). See generally Guandolo, Housing Codes in Urban Renewal, 25 Geo. Wash. L. Rev. I (1956); Note, Enforcement of Municipal Housing Codes, 78 Harv. L. REv. 801 (1965).
} 
The only way to justify exclusive use of housing codes in the attack on the slums would be to assume, as so many are willing to assume, that landlords are heartless monsters reaping enormous, clandestine profits out of the misery of their tenants' lives. There is some evidence that these profits are mythical-at least as a general rule. ${ }^{28}$ No one is certain. What seems likely is that the more dilapidated the building, the lower the profits. It is, however, inconsistent to argue that slum houses are gold mines, and then to worry (as the administration and most housing experts worry) about the difficulties of stimulating investment in low-income housing. Orthodox economists might point out that if housing the poor were truly a gold mine, capital would rush into the market. As a matter of fact, slum housing is a poor business from a number of aspects. It is a high risk, low prestige operation. Apartment houses in the slums need careful management and constant attention to be profitable. Respectable capital is leery of this kind of business. What moves in is uninformed capital, marginal operators-and the disreputable.

But the tenement house laws and housing codes have helped create a climate inimical to normal, respectable investment. These laws have helped create the unscrupulous landlord. They have invited evasion or corruption of formal enactments. And they have done so at least in part because the punitive approach is so cheap and so easy for the government. Passing a housing code calls for the most minimal sort of public investment. Yet it satisfies the outcry to do something about the slums. It names a scapegoat (the landlord), and dumps upon him the whole cost of renovating the national stock of housing. When he fails to respond, government increases its posture of indignation. It authorizes rent strikes, passes receivership laws, and fulminates about taking the profit out of the slums. ${ }^{20}$ The same philosophy lies behind the recent antirioting laws. Congress was faced with demands to do something about big-city riots. Any real program would have been costly and controversial. Congress found it cheap and convenient to name a scapegoat instead and pass a law thundering empty words against the scapegoat. Not a penny had to be appropriated, not a tax dollar raised. Nobody was offended, except the radical fringe.

Government has often hit upon an analogous pseudo-solution to the problem of housing integration. Here government faces a real dilemma. Negroes demand integrated housing. Many white liberals agree, with varying passion and commitment. Other whites violently disagree, particularly small householders in the suburbs and in urban ethnic enclaves. From the standpoint of government, the best solution is to place an ordinance or statute on the books which proclaims the right of Negroes to live everywhere; and to do nothing further. Actually, the form of these ordinances repre-

\footnotetext{
${ }^{28}$ See W. KIEIN, LET IN THE SUN I4I-68, I73-74 (1964); Sporn, Empirical Studies in the Economics of Slum Ownership, 36 Land Econ. 333 (1960). A superb treatment is G. Sternlieb, The Tenement LANDLORD (1966), a recent study of the situation in Newark.

${ }^{20}$ See L. Friedman, Government and Slum Housing: A Century of Frustration, ch. 2 (in press, I967).
} 
sents a quite typical compromise. Those in favor are not strong enough to ram through fair housing laws which really sting; those against are not strong enough to block passage. The compromise takes the form of a ringing symbolic declaration, coupled with flabby enforcement provisions. When these laws fail to be enforced (as is usually the case) the liberals cry out for more teeth.

Yet one wonders if the teeth could really bite. The opposition is numerous and feels the problem deeply. Particularly under these circumstances, the punitive approach is likely to fail. It satisfies only the natural timidity of government. The path followed is much like that of the tenement house laws. First, there is a search for a scapegoat. He is easy to find. The Southern Yahoo, the Polish factory worker, the suburban Bircher-these will do nicely. To castigate these people may be good for the soul and for the adrenalin; it does not integrate a city. To move men and change institutions usually requires more than symbols; it requires the input of actual resources. Those who oppose integration are not merely bigots; they are also frightened men. They are afraid that their property values will decline, that their schools will deteriorate, that police and fire protection will vanish, that crime will rise in their neighborhoods. They feel, in other words, that integration will impose heavy costs on them. They see nobody willing to help them absorb these costs. Government offers preachments and punishments. Politically speaking, a perceived cost is as good as a real cost. Hence, even if the famous decline in property values is illusory, that people believe in it is important. The white opposition to integration will continue to avoid, evade, and frustrate racial integration, as long as they feel that they are asked to bear heavy and unnecessary costs-at no gain to them in any way.

Stimulation has been as popular a device for government as punishment. The idea is to sow seed money, which will induce the private sector to invest heavily in lowincome property. Even before the federal seed money days, many hoped that philanthropists, out of the goodness of their hearts, would solve the slum problem by building model tenements to house the poor. The model tenement movement dates from the middle of the nineteenth century. The philanthropists who built model houses were genuinely animated by a desire to solve pressing problems of society. Perhaps they also wished to demonstrate that respectable private business had both the conscience and the means to do what government could not and would not achieve. Unfortunately, the demonstration failed. Some projects were outright failures; others avoided housing the poorest of the poor, choosing instead to benefit the lower middle class and the honest workman. And volume never lived up to expectations. Capital simply did not flow in any great quantity into the slums. ${ }^{30}$

It became clear that kindhearted millionaires could not, unaided, clear the slums.

${ }^{80}$ See generally on the model tenement house movement, id. ch. $3 ; 2$ J. Ford, SuUMs AND Housing 572-90, 671-701 (1936); E. Wood, The Housing of the UNskilled Wage Earner 9r-I32 (I9I9). A fascinating case-study is Bremner, The Big Flat: History of a New York Tenement House, $6_{4}$ Am. Hist. REv. 54 (1958). 
Gingerly, government tried modest subsidies-the right of eminent domain, tax exemption provisions. ${ }^{31}$

Gradually the incentives have diversified and expanded. Government has become fonder and fonder of the idea, or hope, that private enterprise would rescue it from its housing dilemma. Housing and Urban Development has become an empire of little gimmicks and bailiwicks, programs and subprograms, a bewildering, baffling congeries of devices, many of them motivated by the hope that the market can somehow be galvanized cheaply into life. The government will lend money at belowmarket interest, it will guarantee mortgages, it will subsidize "demonstrations," it will support planning and research, it will encourage tearing down and building up-constantly in search of a key that will magically open a wonderful door of investment. It was recently announced, with trumpets and sennets, from the highest pinnacles in Washington that insurance companies were prepared to invest a billion dollars in the slums. ${ }^{32}$ This development fulfilled so many administration dreams. It met, in part, the demand that something be done about the slums. And it did so at no cost to government, other than the trifling expense of flattering and cajoling executives into taking this step. Moreover, investment by this industry might very well stimulate even more investments by others. Fresh investment in housing in slum areas, by insurance companies, philanthropists, the Roman Catholic church, and whoever else has resources and willingness, is of course very welcome-provided always that demolition, relocation, and rehabilitation are carried on with due attention to human values. But may one be permitted a note of skepticism? Past experience, if it is any guide at all, tells us that private investment is unlikely to make more than a beginning of the job. Low-rent housing must show a profit to attract anyone but philanthropists. And philanthropists are not rich enough, or are too fickle, to mount a sustained attack on the problem. The private effort, then, tends to falter, at which point heavier and heavier subsidies are needed. But it was such subsidies that government wished to avoid in the first place.

\section{Conceusion}

Is there any hope that the poor will be decently housed? At first glance, there seems to be little ground for optimism. All indications are that the problem requires massive public investment. All the political lessons are that this investment is currently impossible. Billions can be voted for defense and for war; even a pittance for domestic programs requires Herculean battle.

\footnotetext{
${ }^{81}$ Act of May 10, I926, ch. 823, [1926] N.Y. Laws 1507. See generally L. Pink, Tre New Day IN Housing 105-14 (I928).

${ }^{83}$ N.Y. Times, Sept. 14, 1967, at 1 , col. $x$ (city ed.). Earlier, President Johnson had "ordered the Department of Housing and Urban Development ... to undertake a pilot program aimed at drawing private resources into public housing . .. [to] involve private developers in not only the construction but also the management of . . projects." N.Y. Times, Aug. 18, 1967, at 1 , col. 2. Such a program would cut criticisms as well as costs.
} 
Technological breakthrough might act as deus ex machina. After all, even the poorest enjoy some amenities of life unthinkable for the rich a century ago. Television is an example. In America, millions of relatively poor people can afford at least a beaten-up nag of a car. This gives freedom, mobility, a chance of change the peasants of India or the textile workers of Victorian England could hardly have dreamt of. Will technology find a way to mass-produce housing for the poor? Some miracle of engineering or science is bound to occur. Experiments in "instant rehabilitation" of slum houses suggest that this is more than a dream.

Technology, however, is no accident. It depends on brute social facts. Innovation flows where it is wanted; it flows where minds and resources have been invested. One can be relatively certain of technological improvement in an industry or field if there is the social will for improvement, a market for the improved product, and investment in research and development. Clearly, there is a market for cheap housing. But there would also be a market for a \$roo new car. The bigger and more lucrative market is the middle class market. The technological hope is tied in with the political and social dilemma of slum housing, and welfare in general. Moreover, technological breakthrough will follow, not precede, massive social investment.

Another possibility is political. The punitive aspects of housing laws were explained, in part, as attempts by government to satisfy maximum demands at minimum price. But some of the classic solutions and responses have begun to pall. They are not working. Demands are not being satisfied. Unrest seems to be growing. Profoundly disturbing riots occurred in big cities in the summer of 1967. Both Negroes and whites appear to have grown more intransigent. Negro militancy means that a new set of demands, stemming from a group that could once be ignored, must now be taken into account. The price of law and order has gone up sharply. Much more output must be allotted by government to the urban poor, if tranquility is to be preserved. And yet the new output-interracial housing, for example-evokes rage and even bloodshed in white communities. It may be that there are no cheap solutions left. The rational course of action may be a difficult and costly one. Investment in slum housing may have to be tripled, quadrupled, to satisfy demands of Negroes and the poor. At the same time, white opposition may have to be bought off, too, by heavy investment in the needs of middle class whites-perhaps with better police protection, schools, street lighting, fire-fighting service. Perhaps bold new devices will have to be tried-price-supports for the little frame houses on the ghetto fringe, to lay the haunting fear of "loss of property values" finally to rest. It is not bigotry but fact that neighhorhoods decay when they become Negro ghettoes. The bigotry consists of the belief that race causes the decay. That the schools deteriorate, that the police stop policing, that the quality of municipal services go down, that buildings become crowded-these are facts, not bigotry. They cannot be met with exhortations. Its costs money to demonstrate that an interracial neighborhood can be a sound, stable neighborhood. It costs money-not fair housing laws or speeches. But 
the politics of urban unrest may eventually drive the country to the point of willingness to spend. And, ultimately, integration and achievement of housing goals means massive public building or subsidizing-scattered housing, suburban housing, vestpocket housing, not high-rise ghettoes near downtown.

Success in this venture is far from certain. In theory, there is a rational solution to every social problem. But an elementary glance at human history shows that the rational solution is not always reached. History is a long dismal tale of wars, disorders, rebellions. It is full of examples of societies that failed to adapt, societies that never found a way to the optimal solution of their problems. The same may be true of urban problems of the United States, and particularly problems of slum housing and the ghetto. Riots, for example, may result not in increased investment but in increased race-hate and increased repression.

As a first step, however, the problem must be stripped of cant, hypocrisy, and obstructive indignation. It has to be seen in all its political, economic, and social complexity. The futility of cheap minimal solutions must become apparent. Only then is there hope of clearing the slums and housing all the people in decent comfort. 